\title{
Pengembangan Media Pembelajaran Komik Matematika Berbasis Problem Based Learning dengan Manga Studio V05 dan Geogebra
}

\author{
Rohati $^{1}$, Sri Winarni ${ }^{2}$, Rafi Hidayat ${ }^{3}$ \\ ${ }^{1,2,3}$ Program Studi Pendidikan Matematika, Universitas Jambi \\ E-mail: ${ }^{1}$ rohatismart@yahoo.com, ${ }^{2}$ sriunja@gmail.com, ${ }^{3}$ rafihidayat2112@gmail.com
}

\begin{abstract}
Abstrak
Penelitian ini bertujuan untuk menjelaskan dan mendeskripsikan bagaimana pengembangan media pembelajaran komik matematika berbasis Problem Based Learning dengan manga studio V05 dan GeoGerba dan menganalisis penggunaan media pembelajaran komik matematika menggunakan manga studio V05 dan geogebra sudah memenuhi kualitas baik pada kelas VIII SMP. Data penelitian diperoleh dengan cara menyebar angket kepada guru dan siswa dan tes hasil belajar siswa. Setelah angket dan tes dikembalikan, data dianalisis secara kualitatif dengan rumus presentase. Hasil penelitian menunjukan bahwa bahwa media pembelajaran komik matematika berbasis Problem Based Learning yang dikembangkan sudah sangat baik, media pembelajaran yang dikembangkan memenuhi kualitas baik, karena memenuhi kriteria valid dengan rata-rata skor 4,33 ini termasuk dalam kategori interval $X>\bar{X}_{l^{+}} 1,8 \times S b_{i}$, dengan kualitas sangat baik. Media pembelajaran memenuhi kriteria kepraktisan, yaitu berdasarkan hasil penilaian guru matematika dengan rata-rata skor 4,45 dengan kategori sangat baik, dan hasil penilaian siswa dengan rata-rata skor 4,478 dengan kategori sangat baik. Media komik matematika berbasis Problem Based Learning memenuhi kriteria keefektifan, yaitu berdasarkan presentasi siswa yang tuntas sesuai KKM adalah 73, 69\%. Menurut Nieveen (1999:126127) kualitas bahan ajar yang dikembangkan haruslah memenuhi kriteria valid, praktis, dan efektif. Maka produk media pembelajaran komik matematika mempunyai kualitas baik.
\end{abstract}

Kata Kunci: komik matematika, Manga Studio V05, Geogebra, PBL

\section{Development of Mathematics Comics Media Based on Problem Based Learning with Manga Studio V05 and Geogebra}

\begin{abstract}
This study aims to explain and describe how the development of mathematics comic learning media based on Problem Based Learning with manga studio V05 and GeoGerba and analyze the use of comic mathematics learning media using manga studio V05 and geogebra has fulfilled good quality in the eighth grade of junior high school. Research data is obtained by distributing questionnaires to teachers and students and testing student learning outcomes. After the questionnaire and test were returned, the data were analyzed qualitatively with a percentage formula.The results showed that the mathematical comic learning media based on Problem Based Learning developed was very good, the learning media developed fulfilled good quality, because it fulfilled valid criteria with an average score of 4.33 included in the interval category $X>\left(X_{-} i\right)^{-}+1,8 \times S b \_$, with very good quality. Learning media meets the criteria of practicality, which is based on the results of the assessment of mathematics teachers with an average score of 4.45 with a very good category, and student assessment results with an average score of 4.478 with very good categories. Mathematical comic media based on Problem Based Learning meets the criteria of effectiveness, which is based on the presentation of students who complete the KKM is 73, 69\%. According to Nieveen (1999: 126-127) the quality of teaching materials developed must meet the criteria of valid, practical, and effective. Then the mathematics comic learning media products have good quality.
\end{abstract}

Keywords: mathematics comics, manga studio V05, Geogebra, PBL

\section{PENDAHULUAN}

Matematika merupakan mata pelajaran yang diajarkan mulai dari tingkat Sekolah Dasar, Sekolah Menengah Pertama, Sekolah Menengah Atas hingga Perguruan Tinggi. Hal ini 
menunjukkan bahwa mata pelajaran matematika merupakan mata pelajaran yang penting. Meski begitu tidak sedikit siswa yang tidak menyukai matematika, mereka beranggapan matematika merupakan mata pelajaran yang sulit karena harus berhadapan dengan konsepkonsep dan simbol-simbol matematika yang bersifat abstrak. Disamping itu tidak sedikit pula guru matematika yang kurang sabar mengajari para siswa yang masih kebingungan dengan konsep-konsep matematika.

Hal ini berakibat pada tingkat pemahaman siswa terhadap konsep matematika menjadi rendah sehingga menimbulkan hasil pembelajaran matematika yang kurang memuaskan. Hal ini dikuatkan dengan hasil rata-rata UN tingkat SMP tahun 2017 sebesar47,75 untuk skala nasional. Untuk rata-rata nilai UN Matematika SMP Provinsi Jambi Tahun 2017 sebesar 43,20 .

Dalam kenyataannya pelajaran matematika sangat penting aplikasinya dalam kehidupan sehari-hari. Termasuk juga materi bangun ruang sisi datar pada pokok bahasan Kubus dan Balok. Kubus dan Balok merupakan salah satu materi pelajaran matematika pada kelas VIII SMP, materi ini sangat erat kaitannya dalam kehidupan sehari-hari. Karena materi ini sering di jumpai dalam berbagai aktivitas kehidupan sehari-hari. Salah satu contohnya seperti bentuk kubus dan balok pada kardus di supermarket. Kanyataannya sekarang masih banyak siswa yang bingung akan materi ini.

Guru hanya menggunakan buku cetak untuk membantu guru menyampaikan konsepkonsep matematika menyebabkan banyak siswa yang kebingungan dalam belajar matematika. Karena media pembelajaran sangat dibutuhkan dan penting dalam kegiatan pembelajaran untuk meningkatkan kualitas pembelajaran yang diharapkan (Rusman, 2012).

Salah satu media pembelajaran yang dapat digunakan dalam proses pembelajaran adalah media komik matematika (KOMAT). Komik sangat membantu siswa dalam belajar di sekolah (Pelton,2009). Pengertian tentang komik dikemukakan salah satunya oleh Toni Masdiono dalam (Mediawati,2011:63) yaitu komik merupakan susunan gambar bercerita dan memberikan pesan-pesan pembacanya. Gambar yang sederhana di tambah kata-kata dalam bahasa sehari-hari membuat komik dapat dibaca oleh semua orang.

Seperti hasil penelitian yang dilakukan oleh (Fadella, Dkk. 2018:85) menunjukkan bahwa muncul rasa tertarik dan ingin tahu peserta didik mengenai isi dari komik tersebut. Hal serupa juga diungkap oleh Toh, T dkk (2017) yang menyatakan komik bisa digunakan sebagai bahan belajar yang menarik untuk siswa. Kesler (2009) juga menyatakan bahwa buku komik bisa disusun oleh guru dan dimplementasikan di dalam kelas untuk belajar siswa. Untuk membantu penulis membuat komik matematika maka disini penulis menggunakan aplikasi Manga Studio V5. Manga Studio V5 adalah aplikasi pembuat manga (komik) yang mudah dan praktis untuk digunakan. Manga Studio 5.0 adalah aplikasi perangkat lunak dengan semua yang Anda butuhkan untuk menggambar manga atau komik ilustrasi, seperti alat pen untuk menggambar secara alami dan dengan real-touch, alat kuas yang memungkinkan berbagai ekspresi warna, dan alat melukis yang mudah digunakan untuk melukis secara efisien dan indah (Anonim, 2013).

Untuk memudahkan pemahaman tentang Kubus dan Balok, maka gambar Kubus dan Balok akan dibuat dengan menggunakan aplikasi Geogebra sehingga gambar akan terlihat 
lebih nyata dan akan lebih mudah dipahami oleh siswa. GeoGebra adalah sebuah pilihan yang tepat untuk berbagai macam presentasi dari objek matematika karena GeoGebra adalah software geometri dinamis yang membantu membentuk titik, garis, dan semua bentuk lengkungan. Menurut Mahmudi (2010) melalui GeoGebra objek-objek geometri yang bersifat abstrak dapat divisualisasi sekaligus dapat dimanipulasi secara cepat, akurat, dan efisien. Program GeoGebra berfungsi sebagai media pembelajaran yang memberikan pengalaman visual kepada siswa dalam berinteraksi dengan konsep-konsep geometri.

Tampilan komik matematika yang menarik menjadikan siswa tertarik untuk mempelajari materi matematika. Ketika siswa termotivasi untuk belajar, ini dapat membuat siswa tertarik untuk menyelesaikan masalah (problem solving). Karena hakikatnya penyelesaian masalah matematika dalam pembelajaran matematika menuntut siswa untuk mampu berfikir kritis, analitis, kreatif, inovatif. Salah satu model pembelajaran yang menuntut siswa mampu menyelesaikan masalah matematika dan menjadikan penyelesaian masalah sebagai landasan untuk menemukan materi matematika adalah model problem based learning (PBL).

Menurut Nurbaiti (2016:104)Problem based learning merupakan suatu pendekatan pembelajaran yang menjadikan masalah sebagai titik awal dalam memulai pembelajaran dan dirancang sebagai pembelajaran yang menuntut siswa untuk memperoleh kemampuan menyelesaikan masalah, kemandirian dan memiliki skill partisipasi yang baik guna mendapatkan suatu pengetahuan baru.

\section{METODE}

Metode yang digunakan dalam penelitian pengembangan media pembelajaran Komik Matematika (Komat) ini adalah metode penelitian dan pengembangan. Pengembangan ini mengembangkan produk komik matematika menggunakan Problem Based Learning pada materi bangun ruang sisi datar pada sub materi kubus dan balok. Menurut (Sukmadinata, 2015:164) penelitian dan pengembangan adalah suatu proses atau langkah-langkah untuk mengembangkan suatu produk baru yang menyempurnakan produk yangtelah ada, yang dapat dipertanggungjawabkan.

Adapun langkah-langkah pengembangan media pembelajaran dengan model ADDIE menurut Branch (2009:2) ditunjukan dalam Gambar 1 berikut:

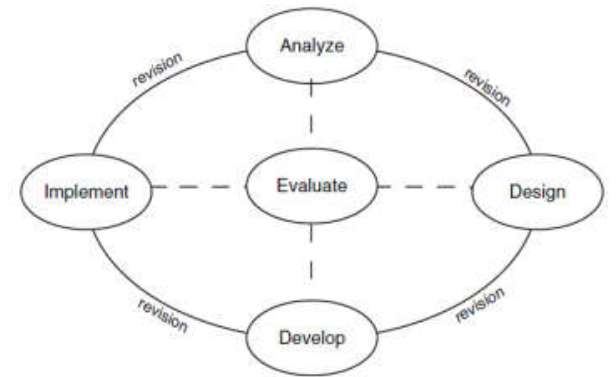

Gambar 1 Model Pengembangan ADDIE (R.M. Branch, 2009:2

Teknik yang digunakan dalam pengumpulan data berupa angket tertutup dan tes. Menurut Muliawan (2014:68) Teknik angket disebut pula teknik kuisioner atau wawancara tertulis. Teknik angket dianggap lebih mudah, terencana, dan dapat dipercaya. Angket tertutup 
merupakan angket dimana pernyataan-pernyataan telah memiliki alternatif jawaban yang tinggal dipilih oleh responden. Teknik Tes merupakan teknik pengumpulan data dimana objek yang diteliti diminta mengerjakan tugas atau pekerjaan tertentu yang diberikan peneliti. Instrumen yang digunakan pada penelitian ini merupakan lembar angket yang mengikuti skala sikap dari Likert yang terdiri dari lembar validasi media komik matematika dan lembar penilaian kepraktisan media komik matematika, dan test yang terdiri dari pre-test dan pos-test yang akan diberikan kepada siswa saat pembelajaran.

\section{HASIL DAN PEMBAHASAN}

Hasil dari penelitian ini berupa sebuah media pembelajaran komik matematika (komat) berbasis problem based learning dengan menggunakan manga studio V05 dan geogebra pada materi bangun ruang di Kelas VIII SMP Negeri 1 Muaro Jambi,

Spesifikasi media komik yang di kembangkan adalah sebagai berikut.

1. Pada bagian pendahuluan di jelaskan standar kompetensi, Kompetensi Dasar, dan Indikator Ketercapaian.

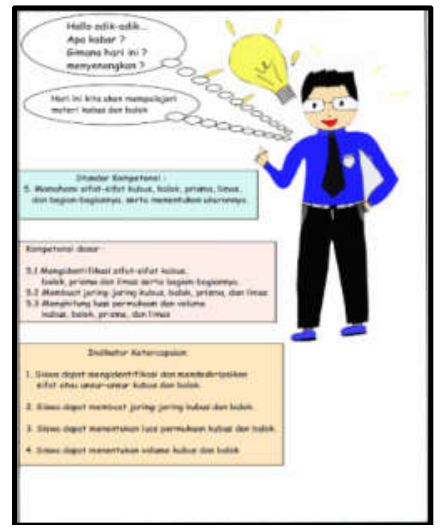

Gambar 1. Penejelasan SK, KD, dan Indikator Ketercapaian

2. Cerita pada komik dibuat 2 chapter yang mencakup materi kubus dan balok

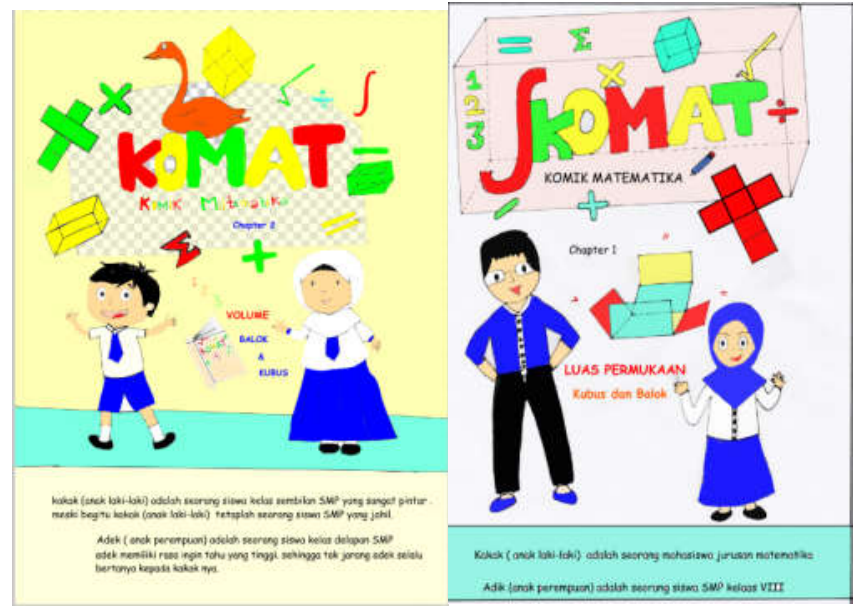

Gambar 2 Cover chapter 1 dan chapter 2 
3. Cerita komik di dasarkan pada permasalahan kehidupan sehari-hari

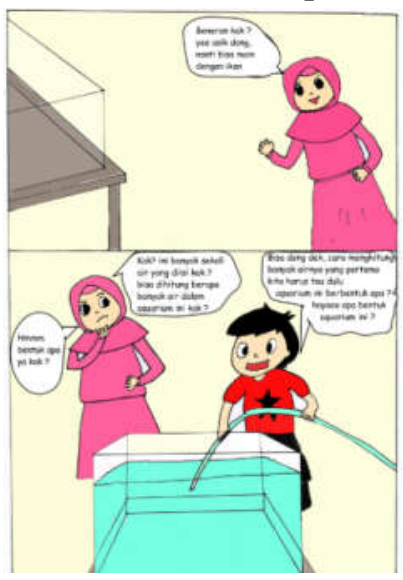

Gambar 3 Permasalahan dalam kehidupan sehari-hari

4. Pembutan komik menggunakan aplikasi Manga Studio V05

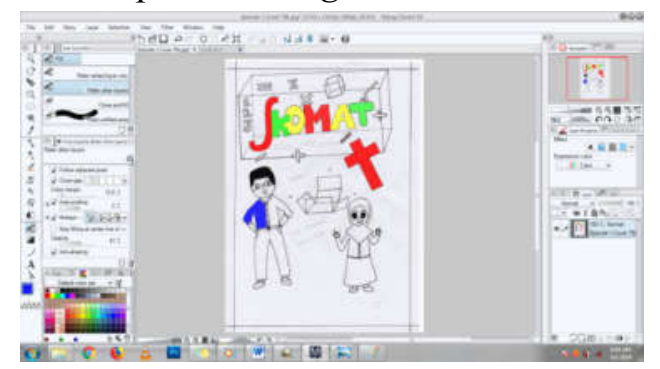

Gambar 4. Pembuatan Komik Menggunakan Manga Studio V05

5. Untuk membuat bangun kubus dan balok di gunakan aplikasi GeoGebra

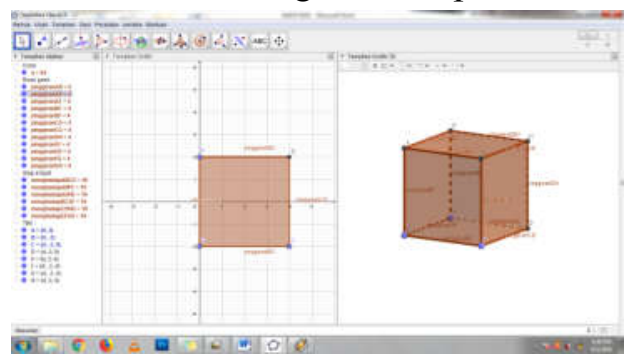

Gambar 5. Pembuatan Bangun Ruang menggunakan aplikasi Geogebra

Penilaian desain media pembelajaran komik matematika materi bangun ruang sisi datar oleh tenaga ahli materi dan tenaga ahli desain pembelajaran, kepraktisan media dari penilaian guru dan siswa kelompok kecil terhadap media pembelajaran yang telah dibuat dengan memberikan angket, dan hasil belajar siswa kelompok besar (kelas sebenarnya) terhadap media pembelajaran komik matematika dengan memberikan post test kepada siswa.

Hasil validasi Ahli dan penilaian guru dan siswa terhadap komik matematika di sajikan dalam tabel 1 berikut. 
Tabel 1 Hasil penilaian komik skala 1-5

\begin{tabular}{clcc}
\hline No. & \multicolumn{1}{c}{ Aspek } & $\begin{array}{c}\text { Jumlah } \\
\text { nilai }\end{array}$ & $\begin{array}{c}\text { Rata- } \\
\text { rata }\end{array}$ \\
\hline 1. & Materi Komik & 85 & 4,047 \\
\hline 2. & Desain Komik & 60 & 4,61 \\
\hline 3. & Kepraktisan komik oleh guru & 89 & 4,45 \\
\hline 4. & Kepraktisan Komik oleh siswa kelompok kecil (6 orang) & 243 & 4,50 \\
\hline 5. & Kepraktisan Komik oleh siswa kelompok besar (satu kelas) & 722 & 4,456 \\
\hline
\end{tabular}

\section{Kevalidan Media Pembelajaran}

Adapun kevalidan media pembelajaran yang telah dikembangkan ditentukan berdasarkan hasil validasi oleh validator yang merupakan ahli di bidangnya.Hasil validasi terhadap desain media yaitu media pembelajaran ini dinyatakan valid dengan kategori "sangat baik" dengan nilai rata-rata 4,61 . Sedangkan hasil validasi terhadap materi yaitu media pembelajaran ini dinyatakan valid dengan kategori "sangat baik" dengan rata-rata 4,047. Adapun hasil rata-rata nilai validasi terdapat desain dan materi pada media pembelajaran ini termasuk dalam kategori "sangat baik" dengan rata-rata skor 4,33.

Berdasarkan hasil validasi media pembelajaran dikatakan valid karena telah melalui proses validasi dan dinyatakan memenuhi validitas isi dan validitas konstruk yang diterapkan oleh orang yang ahli dibidangnya dengan rata-rata skor 4.33 dalam kategori "sangat baik"..

Selanjutnya untuk validasi angket validasi media kevalidan media telah memenuhi validasi konstruk dan diuraikan dalam beberapa pertanyaan-pertanyaan yang berhubungan dengan desain media komik matematika, diantaranya aspek penyajian meliputi ketepatan dialog dengan materi, keruntutan penyajian materi dalam media komik, kejelasan alur cerita yang mendukung pemahaman materi, penyajian gambar dan tokoh menarik, dan penggunaan komik yang mendorong siswa untuk lebih aktif dalam pembelajaran. Kemudian aspek tampilan menyeluruh, meliputi kemenarikan sampul komik, keteraturan desain halaman, pemilihan jenis dan ukuran huruf yang sesuai, kesinambungan antar halaman, kemudahan membaca tulisan, pemilihan warna, kesesuaian cerita, gambar, dan materi serta cetakan komik dilakukan dengan rapi. Maka sesuai dengan teknik analisis data hasil validasi menurut Widoyoko (2009) diartikan validasi media komik matematika dinyatakan valid.

Berdasarkan penilaian validasi materi dan validasi media yang menyatakan valid, maka disimpulkan media pembelajaran komik matematika yang dikembangkan memenuhi kriteria valid sesuai dengan pendapat (Widoyoko, 2009:130) yang menyatakan uji validasi isi dilakukan oleh panel pakar pada bidang yang diukur dan pakar bidang pengukuran. Hasil panel pakar ini merupakan bukti untuk menunjukan bahwa isi tes sesuai dengan materi yang ingin diukur atau diujikan. Selanjutnya (Widoyoko, 2009:132) menyatakan untuk menguji validitas konstruk dapat digunakan pendapat para ahli. Maka dari itu disimpulkan media komik matematika memenuhi kriteria valid karena telah memenuhi validitas isi dan validitas konstruk.

\section{Kepraktisan Media Pembelajaran}

Adapun kriteria kepraktisan diukur dari hasil apresaisi guru dan apresiasi siswa yang ditunjukan dalam proses uji coba produk. Hasil apresiasi guru terhadap media pembelajaran 
yang ditunjukan dalam proses uji coba perorangan didapatkan skor 4,45 dengan kategori "sangat baik" dan tanpa revisi. Sedangkan hasil apresiasi siswa terhadap media pembelajaran ini ditunjukan dalam proses uji coba kelompok kecil dan uji coba kelompok besar didapatkan skor 4,48 dengan kategori "sangat baik" dan tanpa revisi. Oleh karena media itu, media pembelajaran ini dapat dikatakan praktis.

Selain itu media komik setelah dinilai dinyatakan praktis karena materi komik matematika ini telah disesuaikan dengan $\mathrm{KD}$, indikator, tujuan pembelajaran, dan langkahlangkah cerita dalam komik mengacu pada langkah-langkah Probelem Based Learning (PBL). Dari segi kebahasaan guru menyatakan media komik ini telah sesuai dengan EYD Bahasa Indonesia, bahasa yang mudah dimengerti dan pemakaian simbol yang tepat. Sesuai dengan langkah kegiatan belajar yang menyenangkan tidak melalui satu arah guru ke peserta didik saja, media komik matematika dapat menambah minat dan ketertarikan belajar sehingga dengan menggunakan media komik matematika pengetahuan peserta didik akan bertambah.

Berdasarkan pendapat siswa setelah dilakukan uji coba kelompok kecil dan kelompok besar, siwa memberikan penilaian media komik matematika sangat baik. Hal ini terlihat dari angket yang diberikan siswa memberikan nilai 4 (baik) dan 5 (sangat baik). Selain itu dilihat dari komentar siswa setelah menggunakan media komik matematika ini, siswa menuliskan media komik matematika ini sangat menarik, menambah minat belajar, mudah dimengerti, dan sangat baik digunakan. Berdasarkan data yang diperoleh melalui uji coba produk, maka media pembelajaran ini dapat dikatakan praktis karena menurut nieveen (1999) perangkat pembelajaran dikatakan praktis jika guru dan siswa mempertimbangkan perangkat pembelajaran mudah digunakan di lapangan dan sesuai dengan rencana peneliti. Dibuktikan dengan penilaian guru dan siswa yang menyatakan media komik ini mudah dan praktis digunakan.

\section{Keefektifan Media Pembelajaran}

Adapun keefektifan media pembelajaran ini menurut Nieveen (1999) diukur dari hasil belajar siswa setelah belajar dengan menggunakan produk media pembelajaran. Dalam pelaksanaan pembelajaran di SMPN 1 Muaro Jambi penerapan media pembelajaran media komik matematika berbasis Problem Based Learning (PBL) dengan Manga Studio V05 dan Geogebra dapat dilaksanakan. Siswa dapat mengikuti dengan baik pembelajaran tersebut. Hasil analisis data post-test menunjukan presentase siswa yang tuntas dengan KKM 70 adalah $73,69 \%$. Hasil tes menunjukan bahwa media pembelajaran yang dikembangkan memiliki potensial efek terhadap kemampuan siswa dalam memahami konsep.

Berikut di tampilkan contoh soal tes yang diberikan kepada siswa seperti tertera pada Gambar 6. Berdasarkan tabel tersebut jawaban dari siswa bisa berbeda-beda, sesuai dengan pertanyaan yang diberikan. 


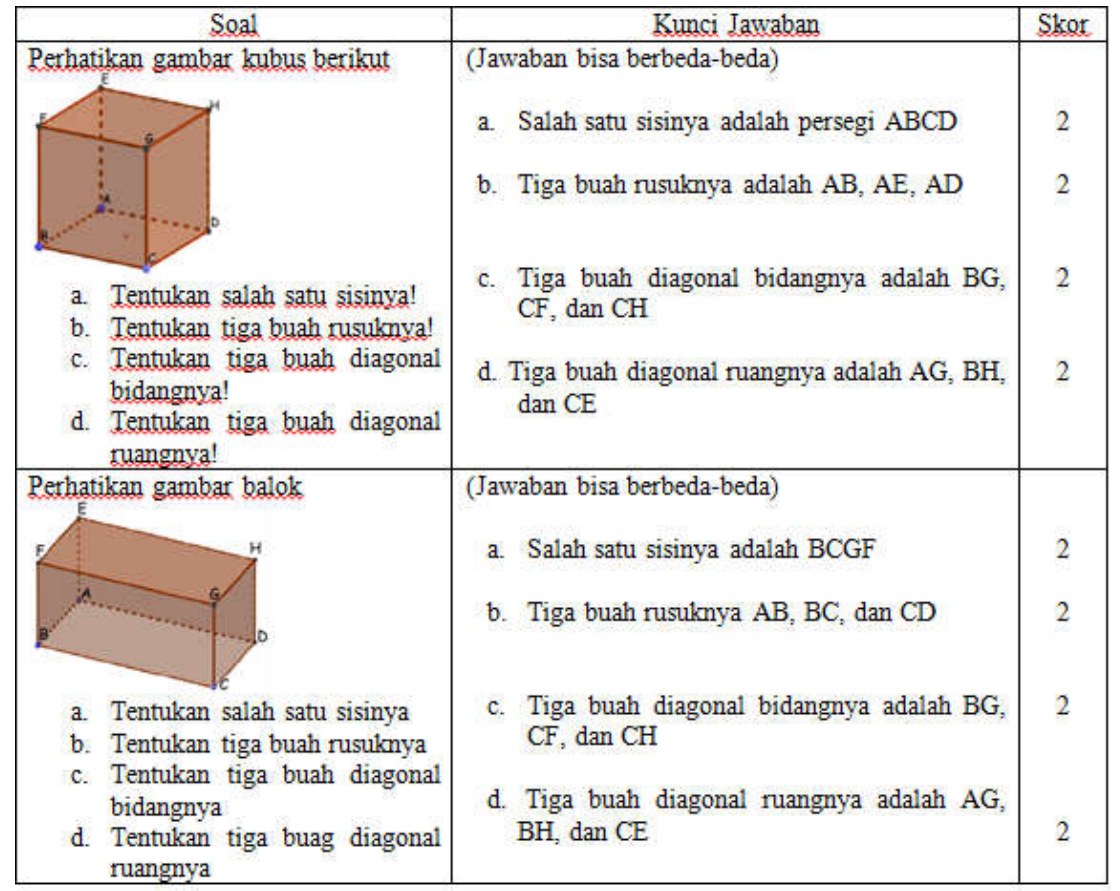

\section{Gambar 6. Soal dan Kunci Jawaban}

Selanjutnya beberapa jawaban siswa ditampilkan pada gambar 7. Dari gambar siswa sudah bisa menentukan sisi dari kubus dan balok. Siswa juga sudah mampu menentukan luas permukaan kubus dan balok.

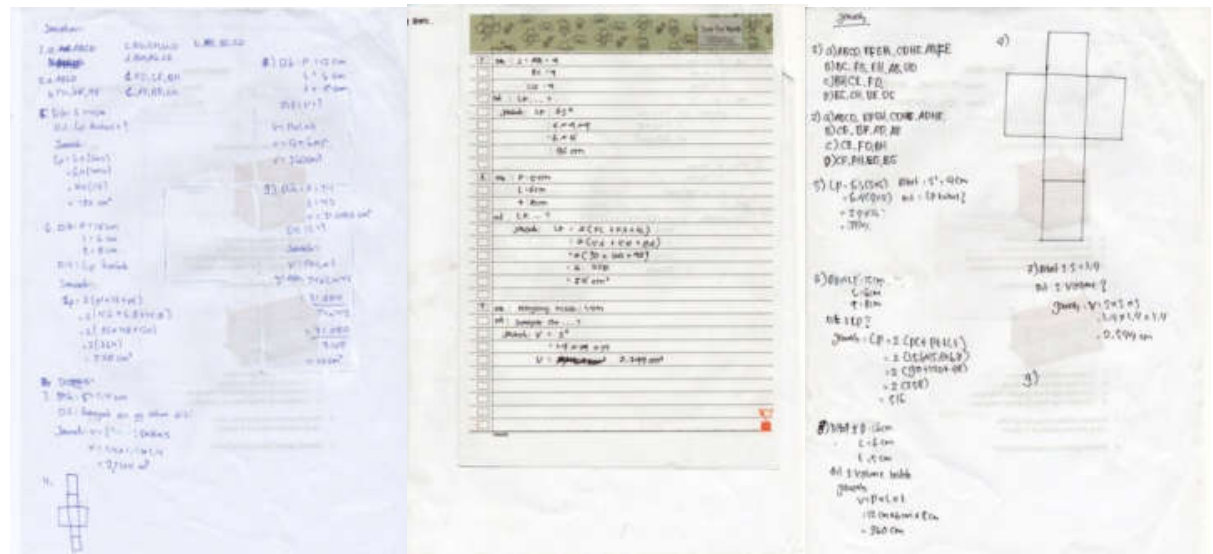

Gambar 7. Contoh Jawaban siswa

Menurut Nieveen (1999:127) ciri ketiga dari produk berkualitas tinggi adalah siswa menerima produk pembelajaran dan kegiatan pembelajaran yang diinginkan terjadi. Maka keefektifan yang peneliti hasilkan disini dapat ditunjukan dengan test hasil belajar siswa (post-test). Media komik matematika setelah dilakukan tes hasil belajar dinyatakan efektif hal ini dikarenakan dalam proses pembuatan media tersebut peneliti menyesuaikan materi yang diajarkan disekolah. Sehingga dalam penyampaian materinya tidak menyimpang dari Standar Kompetensi dan Kompetensi Dasar yang telah disusun. Dalam pembuatan komik tersebut cerita yang diambil berdasarkan cerita dalam kehidupan sehari-hari sehingga peserta didik 
sangat mengenal peristiwa tersebut. Hal ini bertujuan supaya peserta didik dapat memahami bahwa materi tersebut sangat berkaitan dengan kehidupan sehari-hari. Hal ini akan berakibat pada tumbuhnya minat dan motivasi belajar peserta didik meningkat untuk mempelajari materi tersebut.

Selain itu cerita dalam komik disusun berdasarkan langkah-langkah Problem Based Learning, yaitu orientasi siswa pada masalah, mengorganisasi siswa untuk belajar, membimbing penyelidikan individual maupun kelompok, mengembangkan dan menyajikan hasil karya, serta menganalisis dan mengevaluasi proses pemecahan masalahsehingga penerapan pembelajaran menggunakan model Problem Based Learning dapat berjalan lancar dengan menggunakan media komik matematika. Hal ini akan berakibat pada kemudahan peserta didik mengikuti pembelajaran sehingga tujuan pembelajaran yang ingin dicapai dapat tercapai dengan baik.

Disamping itu pembuatan kubus dan balok di buat menggunakan aplilasi GeoGebra yang memungkinkan untuk membuat gambar kubus dan balok semakin menarik dan nyata, serta meminimalisir kesalahan pengukuran pada gambar kubus dan balok. Perpaduan warna dalam komik juga dirasa cocok untuk cerita yang ditampilkan dalam komik matematika. Hal ini dikarenakan pembutaan komik menggunakan aplikasi Manga Studio V05 yang memungkinkan peneliti membuat suatu adegan dalam komik yang hampir mirip dengan kehidupan sehari-hari. Hal ini sesuai dengan penelitian sebelumnya yang dilakukan oleh Agung (2011) Media komik matematika dengan menggunakan model Problem Based Learning (PBL) dinyatakan efektif setelah dilakukan analisis hasil tes siswa.

\section{KESIMPULAN}

Berdasarkan hasil penelitianProduk Media Pembelajaran Komik Matematika berbasis Problem Based Learning(PBL)yang dihasilkan dalam penelitian ini merupakan hasil dari revisi dalam proses pengembangan sesuai dengan model ADDIE. Dalam penelitian ini produk media komik matematika mengalami beberapa kali revisi diantaranya revisi oleh ahli materi dan ahli media. Kemudian dilakukan lagi uji coba perorangan (guru), uji coba kelompok kecil, uji coba kelompok besar. Berdasarkan langkah uji coba tersebut, responden menyatakan bahwa produk media komik matematika yang dikembangkan sudah sangat baik sehingga tidak perlu lagi dilakukan revisi. Produk yang dihasilkan akan di cetak menjadi dua chapter yang akan dibagikan ke setiap siswa sehingga dapat digunakan oleh siswa untuk belajar mandiri dirumah dan dimanapun.

Media pembelajaran komik matematika berbasis Problem Based Learning (PBL) yang dikembangkan dalam penelitian ini termasuk dalam kategori kualitas media yang baik, karena media pembelajaran ini memenuhi kriteria kevalidan, kriteria kepraktisan, kriteria keefektifan.

Dari hasil perhitungan presentase tersebut dapat dilihat bahwa pembelajaran dengan menggunakan media pembelajaran komik matematika berbasis Problem Based Learning $(P B L)$ telah memenuhi standar ketuntasan kelas yaitu jika lebih atau sama dengan $70 \%$ dari seluruh subyek uji coba tuntas.

Berdasarkan hasil penelitian penulismenyarankan untuk dilakukan penelitian komparasi antara media pembelajaran dengan menggunakan Manga Studio V05 dan Geogebra dengan 
media yang lain. Selain itu peneliti juga menyarankan untuk penelitian pengembangan selanjutnya agar dapat mengembangkan media pembelajaran komik matematika dengan menggunakan aplikasi pembuat komik yang lain.

\section{DAFTAR PUSTAKA}

Arsyad, A. 2015. Media Pembelajaran. Jakarta: Rajawali Pers.

Asyhar, R. 2012. Kreatif Mengembangkan Media Pembelajaran. Jakarta:Referensi Jakarta.

Branch, R.M. 2009. Instructional Design: The ADDIE Approach. USE: Springer Science Bisnis Media, LLC, 233 Spring Street, New York, NY 10013, USA.

Fadella, Dkk. 2018. Keefektifan Problem-Based-Learning Berbantuan Komik Matematika Terhadap Kemampuan Pemecahan Masalah dan Rasa Ingin Tahu Siswa. Semarang:Prosiding Seminar Nasional Matematika.

Hidayat, F. 2015. Pembuatan Buku Komik Sawunggaling. Jurnal Pendidikan Seni Rupa, Volume 3 Nomor 3 Tahun 2015, 77-85.

Kessler, B. 2009. Comic Books That Teach Mathematics. Western Kentucky University TopSCHOLAR® Mathematics Faculty Publications Mathematics 1-1-2009

Kimberly, H \& Cotton. (2012). Mathematical Communication, Conceptual Understanding, and Students' Attitudes Toward Mathematics, (Online), (http://digitalcommons.unl.edu/mathmidactionresearch), di akses 5 November 2015.

Mahmudi, A. 2010. Membelajarkan Geometri dengan Program Geogebra. Yogyakarta: Seminar Nasional Matematika dan Pendidikan Matematika 27 November 2010.

Mediawati, E. 2011. Pembelajaran Akutansi Keuangan Melalui Media Komik Untuk Meningkatkan Prestasi Mahasiswa. Universitas Pendidikan Indonesia, Volume 12. No.1. ISSN 1412-565X

Nieveen, N. 1999. Prototyping to Reach Product Quality. Jan Van den Akker, Robert Maribe Braneh, Ken Gustafson, and Tjeerd Plomp (Ed). London: Kluwer Academik Plubishers.

Pelton. 2009. The Learner as Teacher: Using Student Authored Comics to "Teach" Mathematics Concepts. ResearchGate. June 2009

Rohati. 2013. Pengembangan Bahan Ajar Materi Sistem Persamaan Linear Dengan Strategi Problem Based Learning Untuk Kelas X SMA. Program Studi Pendidikan Matematika FKIP Universitas Jambi. ISSN:2008-2157

Rohati \& Febrianto, A. 2015. Mathematics Comics Design With Problem Based Learning Model for VII grade SMP. Prosiding Semirata BKS PTN Wilayah Barat Bidang MIPA di Universitas Sriwijaya, Palembang

Rohman, F. 2006. Modul geogebra workshop 2006.

Sepriyanti, N\&TapiaC. The Development of Mathematics Comics Media on Linear Equations and Linear Inequalities of One Variable. SHS Web Conf. Volume 42, 2018 Global Conference on Teaching, Assessment, and Learning in Education (GC-TALE 2017)

Sukmadinata, N. 2015. Metode Penelitian Pendidikan. Bandung: PT Remaja Rosdakarya. 
Toh, T. L., Ho, S. Y., Cheng, P. P., Jiang, H., \& Lim, K. M. (2017). Using comics in teaching mathematics. In B. Kaur, W. K. Ho, T. L. Toh, \& B. H. Choy (Eds.), Proceedings of the 41st Conference of the International Group for the Psychology of Mathematics Education: Vol. 1 (pp. 277). Singapore: PME.

Widoyoko, S. 2009. Evaluasi Program Pembelajaran. Yogyakarta: Pustaka Belajar.

Yulian, V. N .2018. Developing Teaching Materials Using Comic Media to Enhance Students' Mathematical Communication. IOP Conf. Ser.: Mater. Sci. Eng. 335012110 IOP Conf. Ser.: Mater. Sci. Eng. 335012110 